Supplement of Nat. Hazards Earth Syst. Sci., 18, 463-477, 2018

https://doi.org/10.5194/nhess-18-463-2018-supplement

(c) Author(s) 2018. This work is distributed under

the Creative Commons Attribution 4.0 License.

(c) (1)

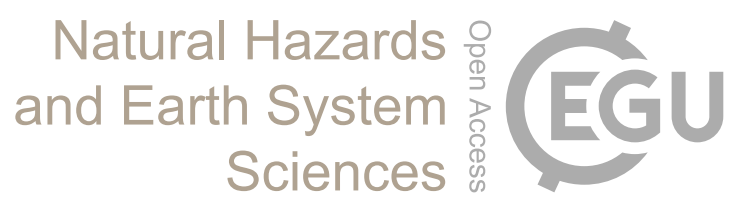

Supplement of

\title{
Investigating compound flooding in an estuary using hydrodynamic modelling: a case study from the Shoalhaven River, Australia
}

Kristian Kumbier et al.

Correspondence to: Kristian Kumbier (kkumbier@uow.edu.au)

The copyright of individual parts of the supplement might differ from the CC BY 4.0 License. 
In the following, we present supplementary remarks and explanations concerning the data and methods in our manuscript.

\section{$5 \quad$ S3.1 Model input data}

Bathymetric points measurements in the Shoalhaven and Crookhaven rivers comprise cross-river points taken every $10 \mathrm{~m}$ while the distance between measured transects was approximately $20 \mathrm{~m}$. Smaller creeks such as Broughton Creek were surveyed with a distance of up to $250 \mathrm{~m}$ between transects. These point measurements were interpolated to a raster surface of $5 \mathrm{~m}$ spatial resolution using an ordinary Kriging method with a spherical semivariogram model.

10 The accuracy of the bathymetric point interpolation (following Chaplot et al. (2006)) was assessed by comparison of interpolated cell values to original point measurements. The interpolated raster (using only $80 \%$ of original data) was compared with a random subset (using $20 \%$ of the original data). The mean error between the interpolated cell values and actual measurements was $-0.05 \mathrm{~m}$ while the root mean square error was $0.91 \mathrm{~m}$. The largest differences were observed in sparsely surveyed creeks.

15 As the bathymetric data set was collected at a time when the intermittent entrance at Shoalhaven Heads was closed, an additional data set of breached entrance conditions originating from 2015 was used to approximate the entrance conditions for the June 2016 storm event. This bathymetric data set of the breached Shoalhaven Heads entrance was provided by the Office of Environment and Heritage (OEH). It was collected after the opening of the intermittent entrance in November 2015 using a jet ski. This post-storm data set was used to adjust the interpolated bathymetry data set of the Shoalhaven River for open

20 entrance conditions at Shoalhaven Heads using a Geographic Information System (GIS).

\section{S3.2 Observational data}

The processing steps of radiometric calibration, terrain correction, speckle filtering and pixel reclassification of the SAR imagery are illustrated in Fig. S1. 

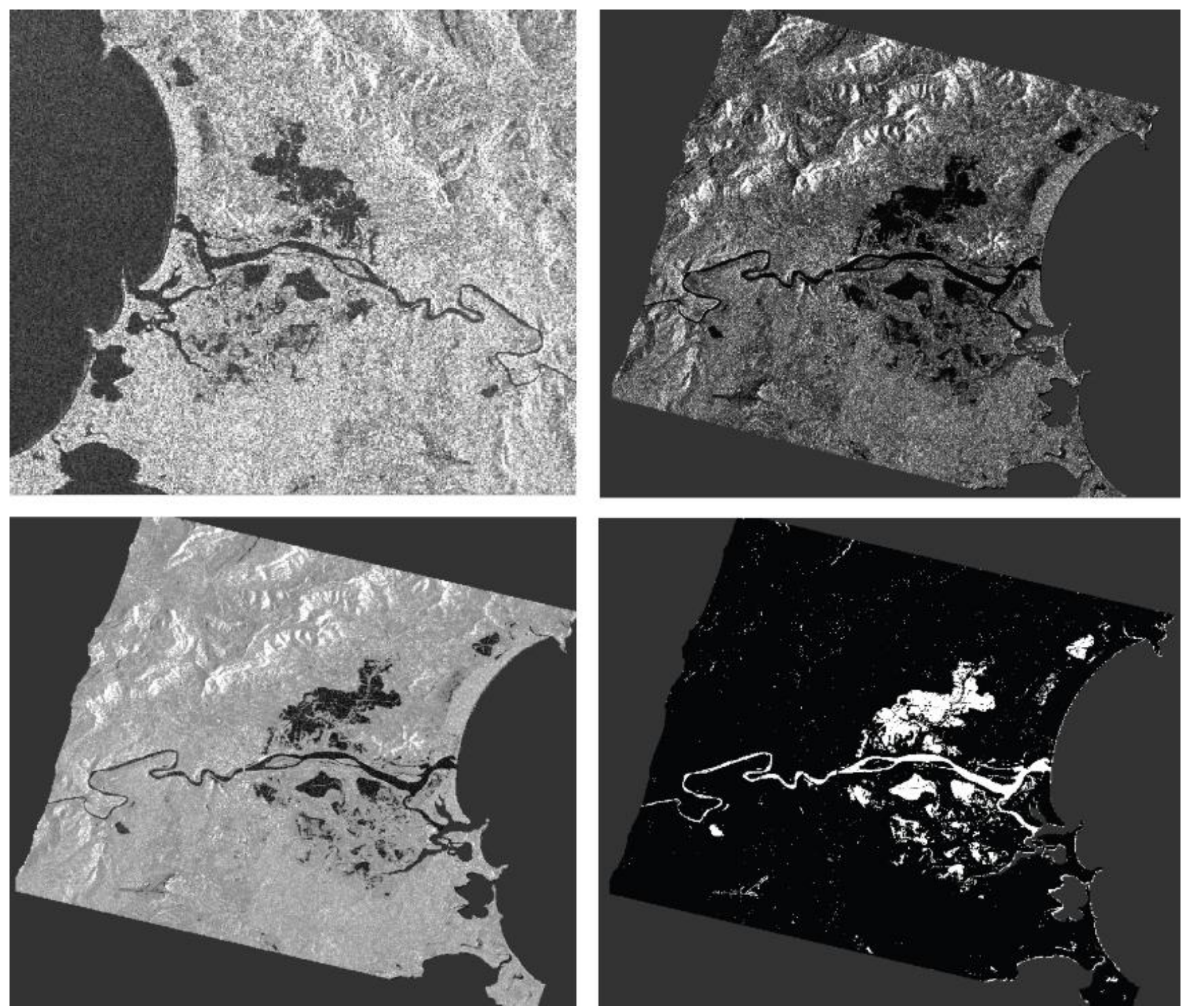

Figure S1: Processing of SAR imagery. Original imagery (top left), calibrated and terrain corrected (top right), speckle filtered (bottom left) and reclassified wet/dry imagery (bottom right). SAR imagery modified after Copernicus Sentinel Data.

\section{Reference}

Chaplot, V., Darboux, F., Bourennane, H., Leguédois, S., Silvera, N. and Phachomphon, K.: Accuracy of interpolation techniques for the derivation of digital elevation models in relation to landform types and data density, Geomorphology 77, 126-141, doi: 10.1016/j.geomorph.2005.12.010, 2006. 